\title{
Jaterní fibróza
}

\section{Václav Šmíd}

IV. interní klinika - klinika gastroenterologie a hepatologie 1. LF UK a VFN Praha

Jaterní fibróza je definována jako nadměrné ukládání extracelulární matrix v jaterní tkáni vedoucí ke strukturálním a funkčním změnám jater. Podkladem těchto změn je nerovnováha mezi procesy fibrogeneze a fibrolýzy, která vzniká jako odpověd' na chronické jaterní poškození bez ohledu na jeho etiologii. Pokročilá jaterní fibróza vede ke vzniku cirhózy se svými možnými komplikacemi - portální hypertenzí, hepatocelulárním karcinomem a jaterním selháním. Pro pacienty s chronickým jaterním onemocněním představuje rozvoj jaterní fibrózy a především její tíže kličový prognostický faktor. Včasná diagnostika je proto z pohledu předcházení vzniku výše uvedených komplikací kruciální. Recentní pokrok v porozumění komplexním molekulárním mechanismům patogeneze jaterní fibrózy a poznání, že se jedná o proces reverzibilní, představuje slibný předpoklad k vývoji cílené protifibrotické terapie.

Klíčová slova: diagnostika jaterní fibrózy, extracelulární matrix, hvězdicové buňky, jaterní fibróza, terapie jaterní fibrózy.

\section{Liver fibrosis}

Liver fibrosis is the excessive deposition of extracellular matrix in liver tissue resulting in structural and functional liver changes. The basis for these changes is the imbalance between fibrogenesis and fibrolysis, which arises in response to chronic liver damage, regardless of its aetiology. Advanced liver fibrosis leads to cirrhosis with its possible complications - portal hypertension, hepatocellular carcinoma, and liver failure. For patients with chronic liver disease, the development of liver fibrosis as well as its severity is the most important prognostic factor. Early diagnosis is a key to avoid above mentioned complications. Understanding the molecular mechanisms underlying liver fibrogenesis is fundamentally relevant to developing new antifibrotic treatments that are independent of the underlying aetiology.

Key words: diagnosis of liver fibrosis, extracellular matrix, hepatic stellate cells, liver fibrosis, therapy of liver fibrosis.

\section{Úvod}

Fibróza jako obecná reakce organismu (včetně jater) na chronický inzult je zodpovědná až za 45 \% úmrtí v industrializovaném světě (1). Její progrese s možným rozvojem jaterní cirhózy představuje logickou odpověd’ na proces hojení jaterní tkáně způsobené akutním či spíše chronickým poškozením bez ohledu na etiologii (viry, bakterie, autoimunitní onemocnění, lékové poškození, cholestáza a mnohé další) (2). Dlouhá léta byla jaterní fibróza predmětem především teoretického výzkumu ve vztahu k rozvoji jaterní cirhózy. S detailnějším pochopením patofyziologických mechanismů a rozvojem široké palety diagnostických modalit se zájem o tuto problematiku přesunul také do klinické praxe (3). Ačkoli vznik jaterní fibrózy a následný rozvoj probíhá obvykle asymptomaticky, její včasná diagnostika se stala jedním z hlavních zájmů klinických hepatologů. Jedině tak Ize včas předejít pozdním komplikacím pokročilé fibrózy, resp. cirhózy, které se zásadním způsobem podílejí na vysoké mortalitě těchto pacientů (4). Rychlost vývoje jaterní fibrózy závisí na vyvolávající prríčině a také na faktorech konkrétního jedince. Obecně však platí, že o prognóze pacientů s jakoukoli chronickou jaterní chorobou rozhoduje vznik pokročilé jaterní fibrózy. Nezbytnost detailního pochopení patogeneze a správného diagnostického algoritmu podtrhuje celosvětově vysoká prevalence jaterní cirhózy a jejích komplikací, kdy např. hepatocelulární karcinom představuje jednu z nejčastějších prričin úmrtí na nádorové onemocnění v celosvětovém měřítku (5). Tyto skutečnosti spolu se znalostí rizikových faktorů umocňuji potřebu adekvátní strategie diagnostiky a léčby jaterní fibrózy.

\section{Patogeneze jaterní fibrózy}

\section{Aktivace hvězdicových buněk \\ a jejich přeměna v myofibroblasty \\ Jaterní fibróza byla dlouhá léta považována za ireverzibilní proces, jehož podkladem je nerovnováha v regulaci syntézy a degradace především}


extracelulární matrix ve prospěch tvorby. Jejím hlavním producentem jsou aktivované myofibroblasty odvozené od portálních fibroblastů a především aktivovaných hvězdicových neboli stelátních buněk (hepatic stellate cells HSC, Itovy buňky, fat storing cells, vitamin A storing cells), které jsou prítomny v Disseho prostorech jaterních trámců, tedy v subendoteliálním prostoru mezi hepatocyty a sinusoidami. Jejich strategické umístění umožňuje těsnou interakci mezi výše uvedenými buňkami a imunitním systémem především ve vztahu k uvolňování cytokinů, chemokinů a regulaci angiogeneze a oxidačního stresu (6). HSC nepředstavují uniformní populaci a pomocí detailního profilování (cytoskelet, fenotyp) je Ize roztřídit do jednotlivých subpopulací (7). Aktivace HSC probíhá působením mnohých faktorů a vede kjejich transformaci v myofibroblasty, resp. ve fenotyp podobný myofibroblastům (8). Tím je iniciován proces fibrogeneze, který je nezbytnou součástí reparace jaterní tkáně. Samotná aktivace neboli transdiferenciace HSC sestává z několika kroků. První bývá označován jako fáze iniciace (někdy také jako fáze „předzánětlivá" z anglického „preinflammatory phase"). Dochází prí ní k bouřlivé odpovědi na celou řadů působků, především cytokinů a lokálních podnětů produkovaných jak imunitními buňkami (např. Kupfferovými buňkami), tak poškozenými buňkami jaterního parenchymu. HSC reagují na četné podněty z apoptotických hepatocytů zvyšováním exprese mRNA pro kolagen typu I, TGFß1 a také a vlákna aktinu. Stejně tak poškození dalších buněčných elementů (buňky žlučových cest, sinusoidů, trombocytů a dalších) vede k profibrogenní odpovědi HSC (9). Kupfferovy buňky pohlcením apoptotických částí těchto buněk a následným uvolněním prozánětlivých cytokinů, růstových faktorů a reaktivních forem kyslíku prohlubují aktivaci a proliferaci HSC. Spouštění této zánětlivé a fibrogenní kaskády vede k trvalejším změnám genové exprese HSC následované změnami fenotypu HSC s přechodem do fáze perpetuace. Ta je charakterizována umocněním nastolených procesů ve vztahu k produkci prozánětlivých, profibrogenních a promitogenních podnětů, které autokrinním i parakrinním působením vedou k výsledným trvalým změnám fenotypu HSC. Mezi klíčové oblasti změny chování HSC patřri: proliferace, chemotaxe/migrace vstríc cytokinovým chemoatraktantům, fibrogeneze, kontraktilita, ztráta perinukleárních depozit retinoidu a dále uvolňování chemoatraktantu z buněk imunitního systému. Výsledkem těchto změn je zvýšená akumulace extracelulární matrix (ECM), některými autory též popsána jako jizevnatá přeměna normální ECM.

Jako rezoluce (rozklad) bývá označována 3. fáze vývoje jaterní fibrózy. Jedná se o proces reparace jaterní tkáně charakterizovaný především dvěma procesy: navrácením aktivovaných HSC do klidového stavu (fenotypu) a/nebo apoptózou aktivovaných HSC. Tento složitý děj je jedním z faktorů podílejících se na extrémní regenerační schopnosti jater a vysvětluje velmi pomalý vývoj jaterní fibrózy u většiny pacientů s chronickým onemocněním jater (10).

\section{Extracelulární matrix a její depozice v jaterní tkáni}

ECM představuje skupinu makromolekul, které vytváři vazivovou kostru jater jak za fyziologických, tak patologických podmínek. Bez ohledu na etiologii jaterního poškození se složení novotvořené ECM zásadně nemění. Její hlavní součástí jsou především tzv. fibrilární kolageny typu I a III, dále v menší míře kolageny V, VI a bazální membránový kolagen IV. Mezi další makromolekuly tvořící ECM patří nekolagenní glykoproteiny (laminin, fib- ronektin, unulin, tenascin), proteoglykany, jejichž součástí jsou také glykosaminoglykany (chondroitin sulfát, dermatansulfát, kyselina hyaluronová) (11). Za fyziologických podmínekje poměr kolagenů I a III vyrovnaný. V průběhu jaterního poškození dochází k významným kvalitativním i kvantitativním změnám. Kolagen typu III vzniká časně, naproti tomu kolagen typu I pribývá pozdně a v cirhotických játrech představuje více než polovinu veškerého kolagenu. Výsledkem produkce těchto sloučenin je vznik fibril v intersticiu, které za fyziologických podmínek obsahuje malé množství ECM podporující správnou funkci okolních buněk predevším ve vztahu k transportu celé řady látek. Nadměrné ukládání ECM v těchto prostorech (iniciálně v subendoteliálních Disseho prostorech), vede k tzv. kapilarizaci sinusoid, procesu, který se zásadní měrou podílí na alteraci jaterních funkcí. Někteři autoři jej nazývají procesem jizvení a již iniciální fáze jaterní fibrózy se může manifestovat klinickými projevy jaterní insuficience (hypalbuminemie, hypoproteinemie, snížená schopnost detoxifikace, koagulopatie a dalších).

\section{Regulace a faktory ovlivňujíć fibrogenezi}

Rovnováha v produkci ECM je za fyziologických podmínek prísně regulována pomocí proteáz degradujicích matrix, resp. kolagen. Tyto kalcium-dependentní enzymy - rodina martixových-metaloproteináz (MMP) - jsou produkovány HSC a specificky degradují kolageny a nekolagenní substráty. Kolagen typu I degraduje MMP-1, mezi dalši významné patři MMP-2, MMP-9 nebo MMP-13. Jejich aktivita je regulována tkáňovými inhibitory metaloproteináz (TIMP), které mohou během poškození jaterní tkáně významně snižovat aktivitu kolagenáz (MMP), což ve svém důsledku vede k poklesu degradace nahromaděné jizevnaté tkáně. Souhrnně tedy kolagenázová aktivita odpovídá relativnímu množství aktivovaných metaloproteináz a jejich inhibitorů. Jaterní fibróza je zcela logicky charakterizována zvýšenou aktivitou TIMP-1 a TIMP-2, což ve svém důsledku vede k akumulaci ECM. Kromě výše uvedeného je aktivita MMP dávána také do souvislosti s invazí nádorových buněk, angiogenezí a kancerogenezí. Další významnou složkou $\checkmark$ regulaci produkce ECM jsou integriny a jejich receptory.

Zcela nezastupitelnou úlohu ve vývoji jaterní fibrózy zaujímají růstové faktory. Výsledkem jejich působení je chemotaxe a proliferace nejen buněk produkujicích ECM, ale také buněk imunitního systému. Jedním z nejdůležitějších a nejsilnějších růstových faktorů je PDGF (destičkový růstový faktor; z anglického „platelet-derived growth factor"), který cestou svého dimerického transmembránového receptoru aktivuje kinázové dráhy s výslednou aktivací HSC. Indukce receptoru pro PDGF svým substrátem vede ke vzniku kontraktilního a fibrogenního fenotypu HSC a nesporně se tak podílí na rozvoji jaterní fibrózy. Dalším potentním růstovým faktorem především ve vztahu k angiogenezi je VEGF (vaskulární endotelový růstový faktor; $z$ anglického „vascular endothelial growth factor"), jehož receptory jsou prokazatelně indukovány během aktivace HSC a ve svém důsledku vedou nejen k prohloubení angiogeneze, ale také se spolupodílejí na mitogenezi a uplatňuji se v pozdních fázích progrese tumorózního procesu přechodem z avaskulární fáze do stádia vaskulárního. Reverzibilita jaterní fibrózy je těsně spjata s mírou jeho tzv. vyzrávání, resp. mírou zasítování (z anglického „cross-linking"). Kličovou úlohu v tomto procesu hraje lysyloxidáza-2 a tkáňová transglutamináza. Výsledný charakter fibrózy, resp. tloušt'ka sept a menší velikost nodulů signifikantně koreluje s horší prognózou. Mezi další růstové faktory produkované HSC patří transformující růstové faktory 
a a $\beta$ („transforming growth factor", TGFa, TGFß) a epidermální rưstový faktor („epidermal growth factor“ - EGF), které navíc autokrinně stimulují proliferaci HSC a vytváŕi tak circulus vitiosus. TGF $\beta$ parakrinně ovlivňuje také proliferaci hepatocytů. Fibrogenezi stimuluje též trombin prímou stimulací proliferace HSC a produkcí chemotaktického proteinu-1, který zvyšuje proliferaci HSC a působí chemotakticky na monocyty. Během chronického poškození jater dochází ke zvýšení produkce fibroblastového růstového faktoru, který se podílí na fibrogenezi a také ovlivňuje činnost hepatocytů.

Jaterní poškození podporuje zkracování telomer, které je typické pro jaterní fibrózu, a především její progresi do jaterní cirhózy s následným vznikem hepatocelulárního karcinomu. Telomery jako sekvence DNA stabilizující chromozomy a tím bránící rozvoji odpovědi DNA na poškození, představují jeden z typických znaků premaligních buněk. Adipokiny, především leptin, který vykazuje jednoznačně profibrogenní účinky na HSC zvyšováním uvolňování TGFß a také snížením exprese PPARy (receptor $\gamma$ aktivovaný peroxizomový- mi proliferátory), je velmi potentním antifibrogenním nukleárním receptorem HSC. Mezi další nukleární receptory podílející se na patogenezi jaterní fibrózy patř́: farnesoid X receptor (FXR), vitamin $D$ receptor (VDR) a také liver $X$ receptor $(L X R)$. Jejich heterogenní účinek ve svém důsledku vykazuje na četných experimentálních modelech významnou antifibrotickou aktivitu.

Ve vývoji jaterní fibrózy mají nezastupitelnou úlohu také buňky imunitního systému. Chronické jaterní poškození je charakterizováno zvýšenou produkcí chemokinů, tedy malých cytokinů s chemotaktickým účinkem. Jejich akumulace díky rezidentním i migrujícím buňkám ř́dí infiltraci tkáně imunitními a kmenovými buňkami a současně podporuje proliferaci rezidentních buněk - především HSC, hepatocytů a buněk endoteliálních. Chemokiny dále podporují migraci fibrogenních buněk na místo poškození. Samotné HSC mají celou řadu receptorů pro chemokiny a kromě jejich aktivace zahrnující migraci, proliferaci, syntézu kolagenu a produkci ROS, mají chemokiny také vliv na další

Obr. 1. Schéma vývoje jaterní fibrózy

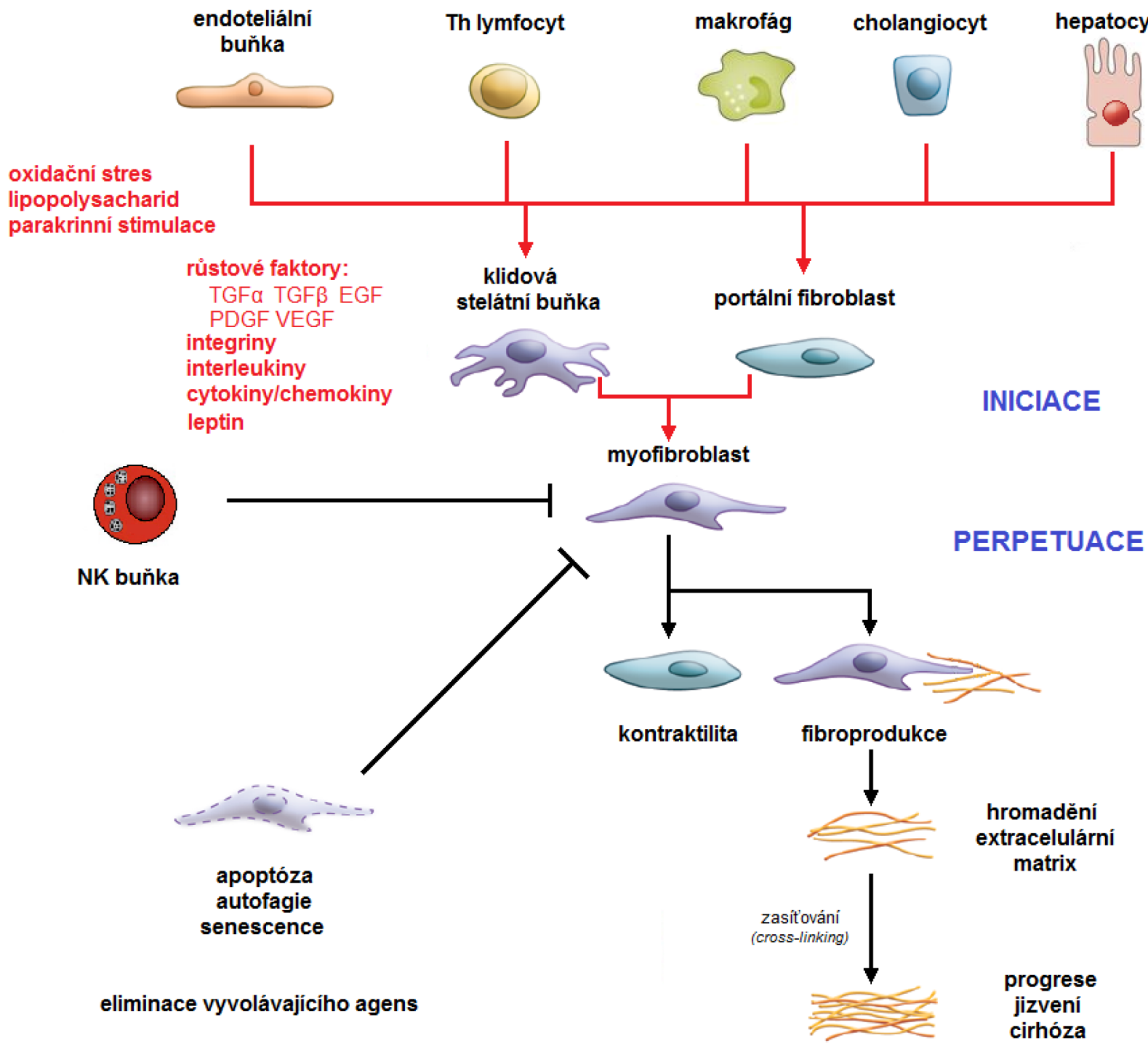

Kličovou roli ve vývoji jaterní fibrózy zaujimmá tzv. aktivace hepatálních hvězdicových (stelátních) buněk (HSC), což ve svém důsledku vede kjejich transformaci ve fibrogenni myofibroblasty. Samotná aktivace HSC je značně komplexní a heterogenni proces odvijejici se mj. od charakteru agens jaterního poškozeni. Obecně aktivace zahrnuje proliferaci, kontraktilitu, fibrogenezi, chemotaxi a také chemoatrakci buněk imunitního systému. Všechny tyto děje vyústujív prohloubení mirry fibrotizace jaterni tkáněs rizikem rozvoje jaterní cirhózy. Terapeutickým cílem je nastolení regrese jaterní fibrózy redukcí aktivace HSC, urychlením buněčného stárnutí HSC a/nebo apoptózou HSC. EGF - epidermální růstový faktor, HSC - hepatální stelátní buňka, PDGF - destičkový rưstový faktor, TGF - transformujicí rưstový faktor, VEGF - vaskulární endoteliálni růstovýfaktor 
produkci cytokinů v samotných HSC. Na eliminaci aktivovaných HSC se významně podílí také NK buňky ( $z$ anglického "natural killer”). Jejich aktivace interferonem y má nejen prokazatelný antifibrotický, ale také protinádorový účinek. NK buňky navíc spolu s Kupfferovými buňkami indukují apoptózu aktivovaných HSC in vitro a také in vivo (12).

Jedním z kličových faktorů ve vývoji jaterní fibrózy je perzistence vyvolávajícího agens. V současné době není exaktně definován „point of no return", tedy okamžik, od něhož je pokročilá jaterní fibróza, resp. cirhóza, již považována za zcela ireverzibilní. Obecně bývá za tento bod označována jaterní cirhóza s noduly, rozvinutou portální hypertenzí a počínajícím jaterním selháním. Stadia předcházející výše uvedenému jsou považována za reverzibilní především v prípadě, kdy je odstraněna vyvolávající príčina, nebo po dosažení její plné kontroly. Četné studie především ve vtahu regrese jaterní fibrózy a terapie chronické hepatitidy $\mathrm{B}$ a $\mathrm{C}$ poukazují na překvapující míru regenerace jaterní tkáně po splnění výše uvedené podmínky.

\section{Diagnostika jaterní fibrózy}

Potřeba přesné diagnostiky jaterní fibrózy vychází predevším z celosvětově vzrůstající incidence chronických jaterních onemocnění a také z faktu, že jaterní fibróza je proces nepochybně reverzibilní. Ve světle těchto poznatků se do popředí dostává potřeba monitorace vývoje jaterní fibrózy v čase a také evaluace efektu zvolené terapie. V tomto pohledu ztrácí své výsadní postavení jaterní biopsie, která byla ještě do nedávné doby považována za zlatý standard v hodnocení tíže jaterní fibrózy. Kromě její ceny, velikosti odebrané tkáně (asi jedna padesátitisícina jater) a rizikovosti (13), je její opakované využití především ve vztahu k hodnocení efektu terapie přinejmenším problematické.

Hodnocení stupně fibrózy na základě histologického vyšetření bylo nejpodrobněji vypracováno u chronických virových hepatitid (především hepatitidy C). V současné době se používají celkem 3 schémata založená na histologickém zhodnocení (Ischak, Metavir, Desme/Scheur), která hodnotí jednak stupeň fibrotizace (F0-F4; nejnižší stupeň znamená absenci fibrózy, nejvyšší stupeň jaterní cirhózu), jednak stupeň zánětlivé infiltrace. Tato schémata nelze jednoduše použít prì hodnocení fibrózy u jaterních chorob jiné etiologie. K histologickému hodnocení tíže nealkoholového postižení jater při steatóze (NAFLD) se používá tzv. NAS score, jehož součástí je také hodnocení míry fibrotizace (celkem se hodnotí 4 oblast - míra steatózy, zánětlivé změny, tzv. balooning hepatocytů a fibróza) (14).

Výše uvedené skutečnosti týkající se problematiky jaterní biopsie vedly k úvahám a následně i praktickému využití neinvazivních postupů v detekci jaterní fibrózy případné cirhózy (15). V současné době se do popředí dostávají 2 velké skupiny metod - sérové/ klinické markery a zobrazovací metody, především pak jaterní elastografie. Nejvíce zkušeností je s využitím metod založených na měření elasticity jaterní tkáně, konkrétně SWE (Shear Wave elastografie), ARFI $^{\oplus}$ (Acoustic Radiation Force Impulse) a FibroScan ${ }^{\oplus}$, o nichž detailněji pojednává recentní článek uveřejněný ve Vnitřním lékařství (Dvořák K. Vnitr Lek 2019, (65)9). Druhou skupinou jsou biochemická a klinická vyšetření spočívající v tomto případě v hodnocení prímých nebo neprímých markerů jaterní fibrózy, tedy takové, které se př́mo nebo neprímo podílejí na tvorbě ECM. Nejjednodušším je poměr AST/ALT, který, pakliže je větší než 1, predikuje pokročilou fibrózu
(16). Obecně jsou v detekci presnější tzv. indexy, mezi něž patři BARD score, APRI, FIB-4 nebo NAFLD fibrosis score. Jednoduchý je tzV. „ALT to Platelets Ratio Index“ (APRI), který je využíván u virových hepatitid (17). Skóre FIB-4 kombinuje ALT, AST, počet trombocytů a věk (18). Původně bylo definováno pro pacienty s koinfekcí HCV a HIV, následně bylo validováno také pro NAFLD. Přímo pro tyto pacienty pak bylo vyvinuto NAFLD fibrosis score, kombinující věk, BMI, glykemii, trombocyty, albumin a poměr AST/ALT, které vykazuje velkou přesnost v detekci pokročilé fibrózy (http://www.nafldscore. com) (19). Komerčně dostupný je pak např. FibroTest ${ }^{\oplus}$, který je spolu s APRI asi nejvíce validovaným testem.

Prímé markery fibrózy jsou založeny na sérové detekci parametrů prímo se podílejících na procesu fibrotizace. Jedná se např. o kyselinu hyaluronovou, TIMP-1 či N-terminální peptid prokolagenu III (PIIINP). Většinou jsou dostupné komerčně jako HepaScore ${ }^{\circledast}$ (20), nebo Enhanced Liver Fibrosis Score (ELF®) (21), které prokazuje velmi dobré výsledky v detekci pokročilé fibrózy u pacientů s nealkoholovou steatohepatitidou (NASH) a Ize jej využít u jaterních chorob různé etiologie. S velkou přesností (92\%) také může prítomnost významné fibrózy vyloučit.

Lze shrnout, že metody neinvazivní diagnostiky jaterní fibrózy jsou již validovány na rozsáhlých souborech pacientů a jejich nespornou výhodou je bezpečnost, neinvazivita a možnost opakovaní vyšetření v čase. Dominantní roli hrají elastografické metody a markery fibrózy, z nichž ty patentované, resp. složitější, vykazují vyšší přesnost v detekci pokročilé fibrózy. Na druhou stranu však jednodušší testy mủžeme využít zadarmo, kdykoli a velmi rychle. Je nezpochybnitelné, že se neinvazivní metody diagnostiky jaterní fibrózy za poslední roky staly klíčovou modalitou v péči o pacienty s chronickým jaterním onemocněním.

\section{Možnosti antifibrotické terapie}

Ačkoli procesy fibrogeneze a regrese fibrózy představují vysoce komplexní a do jisté míry heterogenní děje, detailní objasnění dysregulace HSC na molekulární úrovni přináší nové terapeutické možnosti a strategie léčby pacientů s chronickými jaterními onemocněními. Aktuálně probíhá celá řada studií, které přinášejí velmi slibné výsledky stran efektu prímé antifibrotické léčby. Nadále však platí, že u většiny chronických jaterních chorob je hlavním předpokladem úspěšné léčby odstranění základního vyvolávajícího agens s možností presné a opakované monitorace vývoje jaterní fibrózy v čase (22).

Terminace chronického jaterního poškození je spojena s odstraněním patologického prozánětlivého prostředí a ztrátou aktivovaných HSC. Deaktivace a/nebo redukce HSC s profibrogenním fenotypem proto představuje účinnou terapeutickou modalitu bez ohledu na vyvolávající agens. V teoretickém výzkumu se pracuje především se 2 přístupy:

1. navození nefibrogenního stavu HSC napřr indukcí senescence (stárnutí) HSC nebo pomocí ektopického transkripčního preprogramovaní HSC do buněk charakteru hepatocytů bez fibrogenního potenciálu a

2. prímá indukce smrti HSC, které jsou ve svém aktivovaném stavu velmi rezistentní k signálům vedoucím k iniciaci buněčné smrti.

Mezi potencionální léčebné modality patří např. agonisté PPARa, agonisté farnesoid $\mathrm{X}$ receptoru, nebo blokátory chemokinových recep- 
torů. Účinnou terapeutickou možnost by mohlo představovat navození vnímavosti k signálním kaskádám buněčné smrti (např. NF kB inhibitory nebo proteázovými inhibitory). Jako velmi slibné se jeví využití aktivace NK buněk nebo multikinázového inhibitoru sorafenibu, který indukuje autofagii a apoptózu HSC pomocí signální dráhy JNK/Akt (23).

Další potencionální léčebný prístup představuje indukce degradace ECM, jehož atraktivita spočívá v potencionálním ovlivnění již vyvinuté jaterní fibrózy. K těmto modalitám bývá řazena genová léčba ovlivňující MMP, zabránění upregulace TIMP-1 a TIMP-2 v průběhu aktivace HSC, resp. prímá inhibice TIMP. Dále antagonizace enzymů (lysyloxidáza-2) zodpovědných za tzv. zasítování ECM, což ve svém důsledku vede ke snížení odolnosti ECM k degradaci.

Pro klinickou praxi léčby jaterní fibrózy máme k dispozici nejsilnější soubor dat týkající se terapie chronické infekce virem hepatitidy B a C. Tyto viry, resp. jejich geny a proteiny, prímo i neprímo indukují aktivaci HSC. Ačkoli virus hepatitidy C nemůže prímo infikovat HSC, jeho proteiny (jaderné i nestrukturální) prímo v HSC indukují zánět a profibrogenní dráhy. Dále neprímo cestou růstových faktorů (PDGF, TGF), interleukinů a dalších působků stimulují buňky imunitního systému (např. vyzráváním monocytů v makrofágy) a ty dále svým působením prohlubují míru aktivace HSC. Naproti tomu virus hepatitidy B, presněji jeho e antigen, přímo indukuje aktivaci a proliferaci HSC. Vzhledem k výše uvedenému je žrejmé, že prímá protivirová terapie představuje u hepatitidy B a C hlavní léčebnou modalitu. Tuto skutečnost umocňují rozsáhlé studie prokazujićí:

1. signifikantní míru regrese fibrózy po zahájení protivirové terapie (např. tenofovir v léčbě HBV infekce vedl k regresi fibrózy u 91 \% pacientů (24),

2. významné zlepšení prognózy pacientů, u kterých dojde k regresi fibrózy po eliminaci HCV ve srovnánís pacienty bez známek regrese fibrózy.

Klinického významu nabývá nejčastější chronické jaterní onemocnění současnosti - NAFLD. S celosvětově stoupající incidencí obezity, metabolického syndromu a tudiž NAFLD, stoupá také počet pacientů s pokročilým stadiem této nemoci - NASH. S ní je úzce asociován rozvoj jaterní fibrózy. I pres intenzivní úsilí neexistuje v současné době účinná farmakoterapie tohoto onemocnění a hlavní léčebnou modalitou zůstává změna životního stylu zahrnující změnu dietních návyků, omezení sedavého způsobu života a zvýšení fyzické aktivity. Ačkol existují přesvědčivé důkazy potvrzující efekt těchto opatření nejen na sledované parametry tíže NAFLD, ale také na regresi jaterní fibrózy, největším problémem zůstává nízká míra compliance pacientů ve vztahu k dlouhodobému udržení těchto opatření (déle než 12 měsíců) (25). Účinné se v tomto ohledu jeví bariatrické výkony, které lze však oprávněně aplikovat pouze u malé, predem definované části pacientů s pokročilým NAFLD. Mezi nejslibnější preparáty určené k terapii pokročilé NASH s fibrózou, u nichž probíhá fáze 3 klinického výzkumu, patři cenicriviroc (antagonista chemokinových receptorů 2/5, studie
AURORA), elafibranor (PPARa angonista, studie RESOLVE-IT), obeticholová kyselina (FXR agonista, studie REGENERATE a REVERSE) nebo selonsertib (inhibitor proteinkinázy ASK1; studie STELLAR3, 4). Lze shrnout, že oproti pacientům s virovými hepatitidami budou v budoucnu pacienti s NAFLD velmi pravděpodobně kandidáty antifibrotické léčby.

Četné studie se dále zabývaly efektem modulace (pro)zánětlivé odpovědi jaterní tkáně na chronické jaterní poškození. Signifikantní efekt $\checkmark$ regulaci míry oxidačního stresu byl pozorován např. u vitaminu E, u nějž však vyšší dávky vedly k některým nežádoucím účinkům. Dále byl prokázán pozitivní efekt quercetinu nebo resveratrolu, vykazující inhibici HSC. Protifibrotický efekt flavonoidů byl rovněž príčitán zejména jejich antioxidačnímu pưsobení. I přes tyto slibné výsledky nedošlo k rozsáhlejší aplikaci antioxidantů do klinické praxe $v$ péči o pacienty s pokročilým chronickým jaterním onemocněním (26)

\section{Budoucnost terapie jaterní fibrózy}

Výsledky prímé protivirové terapie jasně prokázaly, že játra mají extrémní schopnost regenerace mj. ve vztahu k resorpci fibrózy. Detailní poznání patogeneze jaterní fibrózy především ve vztahu k dysregulaci intracelulárních a intercelulárních signálů, epigenetickým změnám a buněčným odpovědím na stres představuje potencionální cíle terapie ve smyslu ovlivnění činnosti HSC. Lze očekávat, že se v nejbližší době staneme svědky rozvoje přímé protifibrotické terapie, která může představovat zlom v péči o pacienty s chronickými jaterními onemocněními.

\section{Zkratky}

- ECM - extracelulární matrix

- HSC - jaterní hvězdicová (stelátní) buňka (hepatic stelate cell)

- MMP - martixová-metaloproteináza

- NAFLD - nealkoholové postižení jater při steatóze (non-alcoholic fatty liver disease)

- NASH - nealkoholová steatohepatitida (non-alcoholic steatohepatitis)

- PDGF - destičkový růstový faktor (platelet-derived growth factor)

- PPARy - receptor $y$ aktivovaný peroxisomovými proliferátory

- TGF - transformující růstový faktor (transforming growth factor)

- TIMP - tkáňový inhibitor metaloproteináz

- TNFa - faktor nádorové nekrózy (tumor necrosis factor)

- VEGF - vaskulární endoteliální růstový faktor (vascular endothelial growth factor)

Práce byla podpořena granty MZ ČR - RVO (VFN 00064165) aSVV260524/2020

\section{LITERATURA}

1. Wynn TA. Cellular and molecular mechanisms of fibrosis. J Pathol 2008; 214: 199-210.

2. Bataller R, Brenner DA. Liver fibrosis. J Clin Invest 2005; 115: 209-218.

3. Friedman SL. Liver fibrosis - from bench to bedside. J Hepatol 2003; 38: (Suppl. 1) S38-S53.

4. van der Meer AJ, et al. Reliable prediction of clinical outcome in patients with chronic HCV infection and compensated advanced hepatic fibrosis: a validated model using objective and readily available clinical parameters. Gut 2015; 64: 322-331.
5. Tsochatzis EA, Bosch J, Burroughs AK. Liver cirrhosis. Lancet 2014; 383: 1749-1761. 6. De Leeuw AM, Brouwer A, Knook DL. Sinusoidal endothelial cells of the liver: fine structure and function in relation to age. J Electron Microsc Tech 1990; 14: 218-236.

7. Geerts A. History, heterogeneity, developmental biology, and functions of quiescent hepatic stellate cells. Semin Liver Dis 2001; 21: 311-335.

8. Lee UE, Friedman SL. Mechanisms of hepatic fibrogenesis. Best Pract Res Clin Gastroenterol 2011; 25: 195-206. 
9. Canbay A, et al. Apoptotic body engulfment by a human stellate cell line is profibrogenic. Lab Invest 2003; 83: 655-663.

10. Kocabayoglu P, Friedman SL. Cellular basis of hepatic fibrosis and its role in inflammation and cancer. Front Biosci (Schol Ed) 2013; 5: 217-230.

11. Schuppan D, et al. Matrix as a modulator of hepatic fibrogenesis. Semin Liver Dis 2001 21: $351-372$.

12. Trautwein C, et al. Hepatic fibrosis: Concept to treatment. J Hepatol 2015; 62: (1 Suppl.) S15-S24.

13. Sumida Y, Nakajima A, Itoh Y. Limitations of liver biopsy and non-invasive diagnostic tests for the diagnosis of nonalcoholic fatty liver disease/nonalcoholic steatohepatitis World J Gastroenterol 2014; 20: 475-485.

14. Kleiner DE, et al. Design and validation of a histological scoring system for nonalcoholic fatty liver disease. Hepatology 2005; 41: 1313-1321.

15. Stasi C, Milani S. Non-invasive assessment of liver fibrosis: Between prediction/pre vention of outcomes and cost-effectiveness. World J Gastroenterol 2016; 22: 1711-1720. 16. Angulo P, et al. Independent predictors of liver fibrosis in patients with nonalcoholic steatohepatitis. Hepatology 1999; 30: 1356-1362.

17. Wai $C T$, et al. A simple noninvasive index can predict both significant fibrosis and cirrhosis in patients with chronic hepatitis C. Hepatology 2003; 38: 518-526.
18. Vallet-Pichard A, et al. FIB-4: an inexpensive and accurate marker of fibrosis in HCV infection. Comparison with liver biopsy and fibrotest. Hepatology 2007; 46: 32-36.

19. Angulo $P$, et al. The NAFLD fibrosis score: a noninvasive system that identifies liver fibrosis in patients with NAFLD. Hepatology 2007; 45: 846-854.

20. Guechot J, et al. Automation of the Hepascore and validation as a biochemical index of liver fibrosis in patients with chronic hepatitis C from the ANRS HC EP 23 Fibrostar cohort. Clin Chim Acta 2010; 411: 86-91.

21. Guha IN, et al. Noninvasive markers of fibrosis in nonalcoholic fatty liver disease: Validating the European Liver Fibrosis Panel and exploring simple markers. Hepatology 2008; 47: 455-460

22. Bansal MB, Chamroonkul N. Antifibrotics in liver disease: are we getting closer to clinical use? Hepatol Int 2018; in press; online https://doi.org/10.1007/s12072-018-9897-3. 23. Cohen-Naftaly M, Friedman SL. Current status of novel antifibrotic therapies in patients with chronic liver disease. Therap Adv Gastroenterol 2011; 4: 391-417.

24. Marcellin $\mathrm{P}$, et al. Regression of cirrhosis during treatment with tenofovir disoproxil fumarate for chronic hepatitis B: a 5-year open-label follow-up study. Lancet 2013; 381: 468-475. 25. Romero-Gomez M, Zelber-Sagi S, Trenell M. Treatment of NAFLD with diet, physical activity and exercise. J Hepatol 2017; 67: 829-846.

26. Schuppan D, Kim YO. Evolving therapies for liver fibrosis. J Clin Invest 2013; 123: 1887-1901. 